\title{
Turn Around When Possible: Mapping European Communication Competences
}

\author{
Ralph Tench ${ }^{1}$, Piet Verhoeven ${ }^{2}$, Hasina Juma ${ }^{1}$ \\ ${ }^{1}$ Faculty of Business and Law, Leeds Beckett University, Room 423 Rose Bowl, Portland Crescent, Leeds, LS1 3HB, \\ UK \\ ${ }^{2}$ Amsterdam School of Communication Research, University of Amsterdam, The Netherlands \\ Correspondence: Ralph Tench, Faculty of Business and Law, Leeds Beckett University, Room 423 Rose Bowl, Portland \\ Crescent, Leeds, LS1 3HB, UK
}

Received: September 26, 2014 Accepted: October 22, 2014 Online Published: October 13, 2015

doi:10.11114/smc.v3i2.1138

URL: http://dx.doi.org/10.11114/smc.v3i2.1138

\begin{abstract}
Purpose:

This synopsis of the European Communication Professional Skills and Innovation (ECOPSI) benchmarking Interim Report explains the complex landscape of competencies required by European communication practitioners and explores the underlying constructs that contribute to competence namely skills, knowledge and personal attributes.
\end{abstract}

Design/methodology/approach:

Through a partnership, the methodology draws on the expertise of six leading European universities in communication research around a common goal of mutual interest. The research approach draws on a systematic literature review along with an extensive desk research benchmarking technique conducted by each of the partners. The study builds on prior research on skills and knowledge of communication practitioners.

Findings:

The findings highlight gaps in knowledge about the specific competencies required by European communication practitioners and will underline the current contemporary issues faced by the profession. This information served as the framework for the ECOPSI program (an EU funded research project).

Practical implications:

The synopsis increases awareness of the competence and capability factors of communication professionals in Europe to key stakeholders. It aims to increase understanding of the training and development needs of communication practitioners across Europe.

Social implications:

The synopsis highlights what practitioners consider to be important skills, knowledge and personal attributes across different countries which is essential in today's globalized industry. This contributes to EU mobility targets and expectations for European workers.

Originality/value:

This study benchmarks the educational and practice landscape in six key regions of Europe to demonstrate that the elements focusing on skills, knowledge and personal attributes of European communication professionals can be synthesized using competencies as the foundational element.

Keywords: communication, competencies, skills, knowledge, attributes, education

\section{Introduction}

Twentieth century corporate governance models have been challenged since the 2007-2009 worldwide financial crisis (Sun, Stewart \& Pollard, 2011) and the continuing impact of globalization and technological changes are presenting new opportunities and threats for businesses (Arthur W. Page Society, 2007 and 2013; Werhane, 2012). In order for employees to be successful, they need to navigate through this shifting landscape (Institute for the Future, 2011). 
Employees need to recognize the key competencies required in their role and "will increasingly be called upon to continually reassess the skills they need and quickly put together the right resources to develop and update these" (Institute for the Future, 2011, p. 13). These changes have also impacted the European communication industry over the last five years and consequently, the role of practitioners has changed and they now require a multitude of competencies to be successful in their positions (Zerfass, Tench, Moreno, Vercic \& Verhoeven 2008- 2014).

The objective of this review paper is to gather research on skills, knowledge and competencies of communication practitioners. The intention is to identify gaps in the theory and practice by: (1) clarifying the foundational terms such as roles, skills, knowledge, competencies and personal attributes; and (2) gathering pertinent research on these topics. This information will be instrumental in developing intervention tools for communicators and to accelerate future evolution of the requirements of communication practitioners.

In order to identify the requirements of communication practitioners and managers, it is important to examine the roles and functions of the profession and the expected capabilities of the people working within it. Since 2000, much of the public relations and communications literature has attempted to build on the pre-existing, combined knowledge to create a more detailed view of the nature of the work (Brown \& Fall, 2005; McCleneghan, 2006; Sha, 2011). This has been pitched at a number of different levels of activity and arguably reflects the complex character of communications and its associated activities (Oughton, 2004; Gregory, 2008; Jeffrey \& Brunton, 2011). These levels can be placed in a hierarchy of terms starting at the top with the overall name of the practice, followed by the roles of practitioners, competencies, and skills and knowledge. Each of these levels will be described in detail later in the paper.

\section{Methodological Approach}

This paper is drawn from the literature review conducted for an EU funded research programme, ECOPSI (European Communication Professionals Skills and Innovation Programme - www.ecopsi.org.uk). The ECOPSI project aims to map and evaluate the current and future communication management skills of practitioners across Europe (ERASMUS 2011 Ref No: 517691-LLP-1-2011-1-UK-ERASMUS-ECUE). The project includes partners from the UK, Germany, Spain, Netherlands, Slovenia and Turkey. Partners were chosen from six geographically distinct regions to illustrate how the industry is in different stages of development within Europe, a continent pluralistic in nature. As a result, the views in this paper are representative of the six countries and not all the countries in Europe. In the context of communication research Sriramesh (2009) notes there is a deficiency for international public relations studies. The author believes "one should encourage studies conducted in multiple countries based on the same conceptual framework and research design" $(2009$, p. 8). The ECOPSI programme fills this gap in knowledge by conducting the first pan-European study on communication competencies and capitalizes on making cross-cultural comparisons to add richness to the study.

A systematic literature review that minimizes bias was conducted using Tranfield, Denyer and Smart's (2003) approach during the period of October 2011 to April 2013. The three stages of the review are: (1) planning the review; (2) conducting the review; and (3) reporting and dissemination. The planning of this review began by creating a partnership with six leading European universities in communication research around a common goal of mutual interest. These universities include the University of Leipzig (Germany), the University Rey Juan Carlos in Madrid (Spain), the University of Istanbul (Turkey), the University of Ljubljana (Slovenia), the University of Amsterdam (The Netherlands) and Leeds Metropolitan University (United Kingdom). One professor at each university was selected to be the lead researcher for that country. The main requirement was that this individual be a well-established figure in the field of research. All six professors successfully fulfilled this criteria. In addition, the lead researchers are all members of the European Public Research and Education Association (EUPRERA) with one past president and one current president of this non-profit organisation, which represents all universities in Europe, engaged in education and research in the field.

The ECOPSI programme (Tench \& Moreno, 2015) opted to gain a deeper understanding of the multiple roles practitioners adopt to be successful in the workplace and therefore conducted a review on four distinctly different roles which will have a greater impact on organizations in the future: chief communications officers, crisis communicators, internal communicators and social media managers. A project brief was created and agreed upon. It included the following elements: (1) outlined the scope of the project; (2) defined foundational terms for the project and briefly presented the main debates from the literature; (3) defined the problem and outlined some initial research questions; and (4) outlined a structured format for each country using a benchmarking technique to collect data for their country literature review. Each researcher was assigned to explore the current understanding of communication, skills, knowledge and competencies related to three of the four defined roles. Based on the project brief, the six partners conducted their respective country reviews of the scientific and professional literature in their country and region. One limitation of this approach was that not all researchers were able to find relevant published literature on all of the topics identified in the project brief with comparable depth and as a result, a comparative analysis between each of the topics 
and countries was not appropriate. Reflecting the trans-European focus of the research, not all journal articles collected for this project were in English. If a non-English article was used, then the researcher provided an English synopsis in his/her country review. The English synopsises were written by the lead researcher at each university who were native speakers of the national language and had high proficiency of the English language. This approach minimized the amount of information that was lost in translation. As the ECOPSI director analyzed each of the country reviews, certain review propositions appeared which were mentioned in the introduction (Oughton, 2004; Gregory, 2008; Jeffrey \& Brunton, 2011), starting with the overall name of the practice (A), followed by the roles of practitioners (B), skills, knowledge and personal attributes (C), education (D) and emerging trends and issues (E). These five review propositions serve as the structure for this paper. Due to the limitation of relevant published literature available, contribution from each European partner was included into each of the review propositions where possible. The reporting and dissemination phase began as each partner submitted his/her country review to the ECOPSI director who collated the information into the Benchmarking Preliminary Report (Tench, Verhoeven, Moreno, Zerfass \& Vercic, 2012). This document was the source for this critical literature review and would later be used to create a framework for the ECOPSI project.

\section{Review Proposition A-Naming the Practice}

The literature illustrates there is great debate amongst academics and practitioners around identifying the actual profession or occupation and reaching consensus on the definition of the term (L'Etang, 1996; Moloney, 2000; Grunig, Grunig and Dozier, 2006; Cutlip, Center and Broom, 2006; Toth, 2006; Van Leuven, 2012). There is a range of terms used to describe communications work that takes place in commercial and non-profit sectors in several different countries around the world. For example, the term public relations is arguably the most recognised and understood term used to classify the profession, but is known to be less popular in Europe than in the United States of America because of a belief that the nomenclature has become discredited (L'Etang, 1996; Cutlip et al., 2006). Alternative terms that appear to be interchangeable include "corporate affairs, corporate communications and public affairs" (Dolphin, 2002, p.17). Other terms used in the profession include issue management; investor relations; media relations; internal communication and reputation management (Pieczka, 2002).

\section{Review Proposition B-Role of Practitioners}

\subsection{The roles of Practitioners}

The reviews highlight the extensive research undertaken throughout the partner countries to define those tasks or responsibilities given to communication practitioners by organizations to be performed on a routine basis. This can be pitched at different levels, from fulfilling broad objectives to completing specific small tasks that are the designated specialism of communication professionals (Oughton, 2004; Jeffrey \& Brunton, 2011). Jeffrey and Brunton's (2011) research, conducted in New Zealand, identified two 'superordinate goals' associated with communication management practice. These are: (1) "strategically managing the communication process, and (2) managing relationships" (2011. p.65). The role of communications practitioners is to achieve those objectives. Alternatively, work for the Local Government Communication Leaders Development Programme (Oughton, 2004) in the United Kingdom has identified the core disciplines of local government communication. The most established ones are: (1) consultation; (2) web function; (3) design function; (4) print and publication; (5) advertising, sponsorship and income generation; (6) media relations; and (7) marketing and promotions (p.71). This describes a more prescriptive selection of responsibilities, but still can be described as the role of communication practitioners in an organisation.

In the perspective of reflective communication management and public relations (Holmström, 2010; van Ruler and Verčič, 2005) defined four basic roles for communication professionals: (1) counseling the members of an organization on matters of values, norms and issues important to society; (2) coaching the members of an organization to respond to societal demands; (3) conceptualizing and planning communication with publics to gain public trust; and (4) executing communication plans.

\subsection{Communication Management and 'Doing' Public Relations (PR)}

Research that separates 'management' and 'technical' aspects of PR often use descriptions of the work, which inevitably end up listing activities that constitute either managerial or technical aspects of the practitioner's role (van Ruler, Verčič, Bütschi, \& Flodin, 2000). An example of both the management and technical focus of research can be seen in the European Public Relations Body of Knowledge project where participants found keys skills to be "listening and writing on the one hand and management skills on the other hand" (van Ruler et al., 2000, p.17). More detailed examples of skills include van Ruler's (2000) 10 most common tasks of communication professionals in the Netherlands during the 1990's which focused on mostly technical aspects of the job. Van Ruler and Elving (2007) then clustered tasks of communication professionals into five nuclear roles: (1) the production of texts; (2) managing content and production of websites (internet, intranet, extranet); (3) consultation about means and media of communication; (4) coordination of 
communication projects; and (5) monitoring the quality of communication. The Dutch professional association for public relations, Logeion (2012), developed the ABCD model of tasks and job descriptions of PR and communication professionals (BVC, 2002) further into six nuclear roles: (1) Analysing; (2) Counselling; (3) Creating; (4) Organizing; (5) Guiding or Supporting; and (6) Managing. The terminology used in Logeion's (2012) study is useful because the terms are not too specific and are broad enough to encompass many activities. Technical aspects and managerial tasks are needed to provide a complete view of the contemporary PR landscape as technical tasks help define the profession, and managerial tasks help define the more rounded role.

The European literature review reveals that there are no consistent definitions of roles or of specialisations. There are, however, any number of labels given to types of PR and Communications activities, and any number of titles given to people who perform these sets of activities. It is apparent that identifying the range of duties can be a complex process, especially given the variety of organisational circumstances (Goodman, 2006; Beurer-Zuellig et al., 2009; Liu et al., 2010; Sha, 2011).

\section{Review Proposition C-Identifying Skills, Knowledge and Personal Attributes}

\subsection{Skills}

Proctor and Duttan (1995) developed a practical definition of skills describing it as "goal-directed, well-organized behaviour that is acquired through practice and performed with economy of effort" (p.18). As with the case of identifying the roles of communication practitioners, attempting to specify particular skills that are required to fulfil the requirements of the profession is a complex process. The difficulty comes from a tendency to use different terms to define the same or similar skills. Examples include 'critical' or 'analytical' skills and 'training' or 'coaching' skills. Adding to the complexity, skills are often broken down into sub-skills. Writing for example is a broad skill that includes a multitude of sub-skills such as writing press releases, persuasive writing and speech writing etc (Tench et. al, 2012).

The Corporate Communications Institute's (CCI) Corporate Communication Practices and Trends 2005 study as well as Goodman's 2006 study lists 23 separate skills that form a "skill set necessary for success as a corporate communicator in a global business environment" (Goodman, 2006, p. 203). Of these, respondents identified writing as the core skill with "thorough knowledge of the company and of business principles nominated as essential" (Goodman, 2006, p.203). These two skills and knowledge areas are identified frequently in the literature as very important qualities of communications practitioners (Oughton, 2004; Brown \& Fall, 2005; McCleneghan, 2006; Jeffrey \& Brunton, 2011; Sha, 2011).

McCleneghan notes, "a plethora of published research has documented how important writing is to the PR practitioner" (2006, p.43). He goes on to describe the concerns expressed in a survey of American PR executives about the quality of writing skills among college graduates. This view is supported by Kim and Johnson (2009) and Corner and Cole (2008) whose interviews with members of the Public Relations Society of America revealed that despite 'writing for the news' or 'writing for persuasion' as being the most important PR skill, almost 70 per cent felt that graduates were not well prepared to write in this way. Hardin and Pompper (2004) suggest that this problem may be caused by factors such as fewer graduates coming into the profession with any journalism experience and a 'de-emphasis' of news writing that has emerged among public relations programmes in the United States of America (p.359).

Another key skill area identified in the literature is critical thinking and its related terms such as problem solving, analytical skills or strategic thinking. McCleneghan (2006) ranked critical thinking and writing skills as the most important communication skills from a list of eleven that practitioners must successfully use in practice. DiStaso, Stacks and Botan (2009) put writing skills and critical thinking and problem solving skills as the two most important skills for getting an entry-level job in public relations. Similar to McCleneghan's (2006) findings, respondents felt that hiring individuals for entry-level positions who only sufficiently possessed writing and critical thinking skills was problematic. The complexity of the language used for the many different areas of work means that it is difficult to draw firm conclusions on the current and future skills of communication practitioners.

\subsection{Knowledge}

Some requirements are possibly not appropriately described as skills. In particular, this relates to knowledge of, for example, PR theories or understanding of business and personal characteristics such as integrity, flexibility or team working (Tench et al., 2012). The distinction between knowledge and skills is discussed by Winterton, Delamare-Le and Stringfellow (2005) with knowledge described as an "interaction between the capacity to learn and the opportunity to learn" (p.9). What is learned may involve understanding processes, knowledge of contexts or knowing how to perform certain tasks. The overlap between knowledge and skills may come at higher levels of knowledge which require a certain amount of mental skill to comprehend (Winterton et al, 2005). The literature review revealed a lack of information on the different types of knowledge required by professionals today. 


\subsection{Personal Attributes}

Personal attributes can also be known as employability skills (Ahles, 2004, p.12), which are commonly espoused in the literature as having as much importance as most of the skills and knowledge attributes (Ahles, 2004). Ahles (2004) reports that success in employment depends on having these employability skills which can be broken down into three groups: (1) general professional skills; (2) human relations; and (3) general work habits. The research, based in the United States of America, showed that 60 per cent of respondents ranked human relations skills as the most important skills set. Ahles (2004) suggests that this finding may be due to the particular importance of networking and maintaining good relationships with clients and communities within the profession. Jeffrey and Brunton's (2011) study identified and ranked four types of characteristics. The most important was adaptability which covers common sense, empathy, flexibility and the ability to take criticism. This generates the question of to what extent do personal characteristics matter more than taught skills?

Table 1 provides some indication of the range of skills, knowledge and personal attributes that have been mentioned in the literature as being important to work in PR and communications.

Table 1. Range of skills, knowledge and personal attributes identified in the European literature

\begin{tabular}{lll}
\hline Skills & Knowledge & Personal attributes \\
\hline Writing and oral communication & Business knowledge/literacy & Handling pressure \\
$\begin{array}{l}\text { Project planning and management } \\
\text { Critical thinking }\end{array}$ & Current awareness & Leadership \\
Problem solving & Theoretical knowledge & Integrity/ honesty/ethical \\
Media skills & Knowledge of PR history & Objectivity \\
Persuasion & Knowledge of other cultures & Listening \\
Strategic thinking & Knowledge of communication models & Confidence/ ambition \\
Mentoring and coaching & Knowledge of how to apply PR theory & Team player \\
Advanced communication skills & & Energy/ motivation \\
IT skills (including new media & & Discipline \\
channels) & & Intelligence \\
Crisis management & & Ability to get on with others/ \\
& & interpersonal skills \\
Research & & Wide interests \\
Reading comprehension & & Intellectual curiosity \\
Community relations & & Creativity \\
Consumer relations & & Flexibility \\
Employee relations & & Judgement and decision making \\
Professional service skills & & Time management \\
Social responsibility & & Respect for hierarchy \\
PR ethics & & Follows organisational 'rules' \\
& & Honesty \\
& & Adaptability \\
& & Integrity \\
& & Ambition \\
& & Reliable attendance \\
& Willingness to accept assignments \\
\hline
\end{tabular}

Source: Pieczka (2002), Ahles (2004), Oughton (2004), Brown and Fall (2005), DPRG (2005), Goodman (2006), McCleneghan (2006), Schumann (2007), Gregory (2008), Schick and Mickeleit (2010), Jeffrey and Brunton (2011) and Sha (2011).

\subsection{Competencies}

What is clear from the studies of skills, knowledge and personal attributes is that they overlap in terminology and that there is a pattern forming about how skills, knowledge and personal attributes lead to broader competencies. The literature shows there is considerable debate and difficulty surrounding the definition of competencies and items that contribute to it (Szyszka, 1995; Winterton et al., 2005; Gregory, 2008; Jeffrey \& Brunton, 2011). The European Centre for the Development of Vocational training aims to clarify the concepts of knowledge, skills and competencies (Winterton et al., 2005). This study highlights the usefulness of competencies as providing a link between education (and skills) and job requirements (roles). For example, there is

1. conceptual competence which refers to knowledge about an entire domain;

2. procedural competence which refers to the application of conceptual competence in a particular situation; and

3. performance competence which is required to assess problems and select a suitable strategy for solving them (p.15). 
Szyszka (1995) presents a coherent grid of competencies relevant for public relations practitioners from a German perspective. He differentiates between three categories: knowledge in the field of PR, personal attributes and general education. He offers a fuller explanation of how skills, knowledge and personal attributes contribute to competencies. The competencies depicted can be sub-classified into two categories: (1) specific qualifications - those qualifications which are directly connected to the topic public relations; and (2) unspecific qualifications - those qualifications, like leadership, which can be seen as a core competence for PR practitioners. Both, specific and unspecific qualifications are seen as valuable and relevant to PR practitioners (Röttger, Preusse \& Schmitt, 2009; Schulte 2011). In a study of senior communication managers in the UK, Gregory (2008) defines competencies as "behavioural sets or sets of behaviours that support the attainment of organizational objectives. How knowledge and skills are used in performance" (p.216). Gregory's (2008) research found the emphasis on similar activities within each sector is slightly different. This study effectively distinguishes competencies from skills, knowledge and personal attributes and illustrates the importance to use different language for these different settings rather than attempt some universal catch-all phrases.

Jeffrey and Brunton (2011) highlight the advantage of studying competencies over roles "as ... roles outline tasks and responsibilities in the job description, in today's dynamic workplace these same roles are likely to change frequently. In contrast, competencies are the underlying foundational abilities that are integral to successfully carrying out the tasks and responsibilities, and thus remain a stable blueprint for practice over time" (p.60). Their study identified key competencies required to achieve the organization's superordinate goals that are: "managing stakeholder relationships; external interface management; lobbying; evaluation management; environmental monitoring; and socially responsible communication" (p.65). Jeffrey and Brunton (2011) suggest a competency framework for communications practice should reflect the influences of different cultures and settings and, therefore, more research is required to enhance our understanding of communications practice.

\section{Review Proposition D-Education}

The review of six countries shows education in PR and communication in Europe is very diverse and there are many types of institutions that offer programmes to students. There may be variations in the content, degree structure and standards of each of the programmes. In some countries, the higher education system is divided into two categories: universities and institutions for higher vocational education (that sometimes call themselves universities of applied sciences) with different kinds of degrees. This is evident in countries such as Germany and the Netherlands and in Spain at the post-graduate level. In Germany's case, both types of higher education institutions offer bachelor and master level public relations programmes; however, each programme is quite different in terms of content and standards (Tench et al., 2012).

Most European educational systems have been transforming their degree programmes to adapt to the Bologna Declaration, which was signed in 1999 (European Higher Education Area, 2010). This marked a valuable opportunity for educational institutions to develop national standards and learning outcomes for public relations programmes based on competencies rather than a traditional focus on knowledge for example in Turkey and Spain. This is particularly valuable for Turkey's situation as there were a plethora of education opportunities, but there was no standard for the programmes. In Spain, the reformulation of academic curricula and training provision of the BA in advertising and public relations along with the review of the graduate and $\mathrm{PhD}$ programmes created new enriched educational programmes especially at the undergraduate level. Despite the growing academic interest in public relations, the discipline is still a subordinate of advertising and not equal to other disciplines such as marketing or political communication (Tench et al., 2012). As European educational institutions embark on the Bologna process, it is hoped graduates, regardless of their country of study, will embody a common set of competencies that are relevant for today's professional context.

\subsection{Post Graduate Education and Research}

The literature reviews revealed that European countries are at different stages of development when it comes to post-graduate education.

\subsubsection{The United Kingdom Experience}

The United Kingdom country review developed discussions emerging from an English language literature review and therefore includes North American publications. For example, three of the most prominent findings from The State of Public Relations/Communication Management Master's Degree Education in the United States published by Commission on Public Relations Education (2011) are: (1) lack of uniformity in curriculum across programmes; (2) the needs for business and management knowledge; and (3) the value of post graduate qualifications in comparison to with what is gained through work experience.

Toth and Aldoory (2010) studied public relations education internationally, observing that it is "generally based on 
several universals and yet is often combined with local variations" (p.2). They found that most of the participants in their study who were public relations educators from 20 different countries expressed some version of the standards recommended by The Professional Bond (Commission of Public Relations Education, 2006). There appears to be some consensus that a master's degree provides an opportunity for communications professionals to obtain some general business and management skills that will be useful when senior positions are reached in practice. Drake (2006) has observed that post-graduate PR education is useful for those existing practitioners who have never been formally trained or were trained so long ago they need to refresh their knowledge and skills. A master's degree taken after gaining a few years of experience was considered useful for developing strategic and business knowledge as well as the use of research methods. However, Parnell (2008) reports on a survey of communication recruiters and executives which found that advanced degrees are considered to be most beneficial at the start of a career while industry experience was still valued more than a master's qualification. However, an advanced degree was considered to be a potential difference maker when experience levels are similar among candidates and was thought to be helpful for getting into leadership positions when combined with industry experience. In addition, Toth and Aldoory (2010) describe the purpose of most (post) graduate programmes as providing "working professionals with advanced understandings in theory and research in order to go back to the profession and gain higher-paying, higher status positions" (p.15). Uncertainty remains over whether a post-graduate study is time well spent or whether that knowledge can be developed through experience in the field.

\subsubsection{The Experiences in Spain and Turkey}

In Spain, there is not a solid tradition of academic research on public relations. There is a significant lack of theoretical research tradition especially in the area of current training programmes and competencies required to perform specialized professional roles (Tench et al., 2012). Similarly, in Turkey, Okay and Okay (2008) concluded that the contribution from MA and doctoral dissertations towards public relations' improvement, especially in theory building, was negligible from 1984 to 2007. One of the reasons for this issue is a limited number of educated academics on the subject despite the increasing number of communication faculties, i.e. universities.

\subsection{Academic Theory}

There is a dilemma that exists between the importance of academic theory to the credibility and professionalization of the discipline. Botan and Taylor (2004) promote the value of public relations theory by stating it has "the potential to unify a variety of applied communication areas and serve different types of organizations" (p.659). Moncur (2006) highlights the potential contribution of theory as providing a "vocabulary whereby practitioners and academics can communicate to develop a better understanding of the subject and its potential" (p.96). In terms of teaching theory to PR students, Latchaw, Allan and Ogden (2009) argue that its purpose should be to enable students in researching and designing campaigns and more generally to enhance their critical analysis abilities as very important among employers in the profession. However, Cheng and Gregorio's (2008) survey of PR academics found that although they are generally in favour of building closer ties with industry, practitioners are considered by the academics to be indifferent to theories and academia in general. Pieczka (2000) and Moncur (2006) to some extent share the view that this is due to philosophical differences between practitioners and academics (see also van Ruler, 2005) with the former being focused on organisational goals and practical markers of achievement and the latter more concerned with abstract concepts and understanding the fundamental questions of communication. Academics keep putting forward the notion that for the professionalization of the practice to continue, a closer connection to communication and social theory and to scientific empirical research is needed (Ihlen \& van Ruler, 2007; Ihlen, van Ruler, \& Fredriksson, 2009; Ihlen \& Verhoeven, 2009; 2012).

\section{Review Proposition E-Emerging Trends and Issues}

\subsection{Social Media}

The interactive platforms that form the central axis of social media have modified the paradigm of communication within organizations. Social media usage and adoption is argued as increasingly mainstream (Brown, 2013). The findings in the European Communication Monitor (Zerfass et al., 2012) indicate more than 46 per cent of communication professionals believe that coping with the digital evolution and the social web is the most important strategic issue for communication management until 2015 (Zerfass et al., 2012). The European Communication Monitor data suggests that the introduction of new technologies for communication requires organizations to communicate using an alternative model founded on listening and speaking. This new environment has complicated who controls the message (Celaya, 2008; Capriotti, 2009; Castelló, 2010; Colorado, 2011). This notion is reinforced by Linke and Zerfass (2013) who uncovered the main obstacles for German communication professionals from a governance perspective are lack of knowledge and experience of conceptual approaches to social media (pp. 278-279) with 66 per cent relating to loss of control of communication processes and 64 per cent the need for quick reactions. In the Spanish 
literature there is debate around the role and competencies of social media managers. Alcántara (2011) states the ideal practitioner would be a community manager who has extensive knowledge about online communication strategies in order to reach the community in an effective manner. Monge (2010) states that every behaviour of a community manger has be supporting and strengthening the brand value online while other researchers such as Rojas (2011) set out a wider set of responsibilities to cover products, brand and the organization. When examining the relationship between the use of social media platforms and power, Diga and Keelleher's (2009) research showed using these platforms helps to build a practitioner's social capital that then leads to increased status or prestige. The study notes that additional research needs to be conducted on the link between the use of social media tools and the roles of practitioners. The literature review shows knowledge and understanding of the role of social media in communication work as well as the competencies required by professionals is limited and is still developing among practitioners and academics.

\subsection{Evolving Communication Skills Issues}

Some skills requirements have had prominent coverage in the academic literature over the past decade. They have not necessarily been considered as 'core' skills in the past, but now appear to be almost essential to communication practitioners (Hatzios, 2006; Edwards, 2008; Evan, 2011; Arthur W. Page Society; 2012).

The recognition of the importance of local variations along with the impact of the globalised economy emphasises the requirements on the modern practitioner to maintain an understanding of culture in a variety of different, often international-settings (Rose, 2002; Creedon \& Al-Khaja, 2005; Hatzios, 2006; Freitag, 2002; Bardhan, 2003; Fleischer, 2003; Toth \& Aldoory, 2010). There have been several papers published in the last decade emphasising the importance of international public relations and cultural awareness in the profession. The issues covered include the acknowledgement of different cultures within and between countries (Rose, 2002; Creedon \& Al-Khaja, 2005), language skills and experience of living abroad (Hatzios, 2006) and making space for international public relations in degree-level courses (Freitag, 2002; Bardhan, 2003; Fleischer 2003; Creedon \& Al-Khaja, 2005; Hatzios, 2006; Toth \& Aldoory, 2010).

Research by the Arthur W. Page Society (2012) reveals that with the advent of digital devices and tools, individuals are now the generators of knowledge. In 2000, only 5.8 per cent of the world had access to the Internet compared to 40 per cent in 2013 (ITU, 2013). In the past individuals were only connected to the Internet through desktop computers, but with the advances in technology there were 8.7 billion Internet connected devices in 2012 (Soderbery, 2013). This number is estimated to grow to 25 billion in 2015 and will surpass the estimated global population of 7.2 billion people (Evans, 2011). In a world of Internet of Things (Evans 2011), combined with an explosion of data, the public relations practice is "moving from mass communication aimed at segments and publics through intermediaries to engagement with people based on understanding them as individuals - as revealed in the data and perspectives" (Arthur W. Page Society, 2012, p 12). Communication professionals especially CCO's are challenged to learn new competencies so they can gather information and transform it into knowledge and wisdom (Arthur W. Page Society, 2012; Juma 2013).

\subsection{Professionalization of $P R$ and Communications}

Recent literature relating to the professionalization of PR and communications highlighted several relevant issues to the identification of the skills needs of modern practitioners (van Ruler, 2005; Sha, 2011a; Coleman \& Wilkins, 2009). A profession can be defined by various means and those occupations striving for professional status may adopt various tactics that may be aimed at enhancing reputation or generating a body of knowledge or method that emphasizes uniqueness and credibility (van Ruler, 2005). Some doubts have been expressed about how successful communications and PR has been in becoming fully professionalized (Edwards, 2008, Edwards, 2012). Some, in fact, have suggested that the industry's lack of professionalism is its strength (L'Etang, 2002; De Bussy \& Wolf, 2009). Steiner (2001) argues that the narrow definitions that are implied by professionalism conflicts with the valued complexity and diversity of communications work.

\section{Summary}

As the communication industry continues to undergo phenomenal change largely driven by pressures to improve profits and to make cost efficiencies, developing and acquiring competent communication practitioners is imperative. This critical review demonstrates there is literature that focuses on the skills, knowledge and personal attributes of practitioners whereas practitioners' competencies-a concept that is more abstract-attracts less scholarly attention. Much of the research across Europe focuses on communication management, which involves identifying activities typically undertaken by practitioners. There are also no consistent definitions of the roles or of specialisations, such as a social media practitioner or internal communications practitioner. There are, however, any number of labels given to types of public relations/communication activities and any number of titles given to people who perform these sets of activities. Identifying specific skills, knowledge and personal attributes of practitioners is also a complex matter as there is a tendency to use different terms to define the same or similar attributes. In particular, the review revealed there is a lack 
of information on the different types of knowledge required by practitioners today. Even though there is a great debate amongst academics on how the combination of knowledge, skills and personal attributes leads to competencies, there is agreement that competencies are foundational abilities that are stable over time unlike roles that are continually evolving. One of the drawbacks from existing studies on competencies is that they have conceptualized practitioner roles, but have not identified competencies for each role. An example is the European Public Relations Body of Knowledge project (van Ruler et al, 2000). Some academics such as Jeffrey and Brunton (2011) suggest that a creation of competency framework for the practice based on research that takes into account how the culture of a given country influences the practice in an individual country would help to enhance our understanding of the communication practice.

As the worlds of communication, technology and culture continue to collide, it is important for practitioners to acquire new competencies in order to have continued success in their roles within the global workplace. The review highlighted how skills such as writing, critical thinking and problem solving have endured as key requirements for practitioners, but other areas of knowledge such as cultural awareness, the ability to analyze volumes of data and use of social media in a strategic manner are emerging as essential skills for communication practitioners. The realm of social media and the competencies needed to perform this role successfully is an area that requires further research from practitioners and academics. Table 2 summarises the major gaps and/or issues identified in this comprehensive literature review.

Table 2. Summary of major gaps and/or issues highlighted in the literature review

\begin{tabular}{|c|c|c|}
\hline Section & Sub Heading & Major Issue or Gap \\
\hline \multirow{2}{*}{\multicolumn{2}{|c|}{$\begin{array}{l}\text { 3.0. Review Proposition A } \\
\text { - Naming the Practice } \\
\text { 4.0. Review Proposition B } \\
\text { - Role of Practitioners }\end{array}$}} & $\begin{array}{l}\text { There are a range of terms to describe the work of the } \\
\text { professional. } \\
\text { There are no consistent definitions of the roles or specialisations } \\
\text { within the Communication/PR industry. }\end{array}$ \\
\hline & & $\begin{array}{l}\text { A mixture of profession -specific knowledge and a range of } \\
\text { personal attributes are necessary determinants of excellence } \\
\text { among communication managers. }\end{array}$ \\
\hline \multicolumn{3}{|c|}{ 5.0. Review Proposition C - Identifying Skills, Knowledge and Personal Attributes } \\
\hline & 5.1. Skills & $\begin{array}{l}\text { There is a tendency to use different terms to define the same or } \\
\text { similar skills. }\end{array}$ \\
\hline \multirow{6}{*}{$\begin{array}{l}\text { 6.0. Review } \\
\text { D: Education }\end{array}$} & 5.2. Knowledge & $\begin{array}{l}\text { There is a lack of information on the different types of knowledge } \\
\text { required by professionals today. }\end{array}$ \\
\hline & 5.3. Personal Attributes & $\begin{array}{l}\text { The following question needs to be answered: To what extent do } \\
\text { personal characteristics matter more than taught skills? }\end{array}$ \\
\hline & 5.4. Competencies & $\begin{array}{l}\text { There is considerable debate and difficulty surrounding the } \\
\text { definition of competencies and the items that contribute to it. }\end{array}$ \\
\hline & & $\begin{array}{l}\text { Education in PR and communication in Europe is diverse and } \\
\text { there are variations in the content, degree structure and standards } \\
\text { of each of the programmes. }\end{array}$ \\
\hline & $\begin{array}{l}\text { 6.1.Post graduate education } \\
\text { and research }\end{array}$ & $\begin{array}{l}\text { European countries are at different stages of development when it } \\
\text { comes to post-graduate education. }\end{array}$ \\
\hline & 6.2.Academic Theory & $\begin{array}{l}\text { There is a dilemma that exists between the importance of } \\
\text { academic theory to the credibility and professionalization of the } \\
\text { discipline. }\end{array}$ \\
\hline
\end{tabular}

7.0. Review Proposition E: Emerging Trends and Issues 7.1. Social Media

The role of social media in communication work as well as the competencies required by professionals is limited and is still developing among practitioners and academics.

7.2. Evolving The review shows how other areas of knowledge such as cultural

Communication Skills awareness, the ability to analyze volumes of data and the use of Issues social media in a strategic manner are gaining greater importance in comparison to traditional skills like writing and critical thinking.

There is a lack of research on social media practice within the PR sector, and the skills, knowledge and personal attributes needed to perform this role successfully.

7.3. Professionalization of Although there is a drive towards professionalism, it remains PR and Communications inconsistent and the responsibility to professionalise PR within specific countries is spread across professional bodies, accredited universities and private education institutes, with little coordination.

\section{Future Research}

There is no empirical research that brings the elements of skills, knowledge and personal attributes together in a 
Europe-wide study. Empirical research could fill the gaps of knowledge 5.0-5.4, and 7.0-7.3 as identified in Table 2 by: (1) Identifying which competencies are needed for social media roles, internal communication roles, crisis communication roles, and communication director roles; and (2): Identifying the skills, knowledge and personal attributes that are perceived to be important for each competency, in each of the four roles. The empirical part of the ECOPSI project will carry out a collaborative qualitative and quantitative research programme across Europe working in six country contexts including the Netherlands, Germany, Spain, Slovenia, the UK and Turkey. Gregory (2012) notes that by analysing and understanding the impact of culture on the methodological design of international cross-cultural research projects, the researchers can share a common purpose and achieve the desired aims successfully. Gregory's (2012) five-step process will be critical to ensure the research is initiated, framed, implemented, maintained and completed in a culturally sensitive manner.

This paper provides increased awareness of the competence and capability factors of communication professionals and provides a basis for empirical research. This review suggests there is a need for culturally-based research which could help offer guidance as to whether certain principles can and should be taught within certain cultures, and what should be emphasised in each culture. Empirical findings are necessary to produce broad guidelines and additionally to encourage European professional associations, specifically those identified in the six regions of this paper, to use the proposals and recommendations based on both analytical and empirical results for their practices.

\section{Acknowledgements}

The authors would like to acknowledge the funding support provided from the European Commission to actualize the ECOPSI project.

The authors would like to thank their ECOPSI co-researchers, Dejan Vercic, Angeles Moreno, Ayla Okay, Ansgar Zerfass and research associate at Leeds Beckett University, Ben Mitchell.

\section{References}

Ahles, C. B. (2004). PR skills vs. personal skills: what matters most to the boss?. PR Tactics, 12-13.

Alcántara, L. R. (2011). El Community Manager como pieza clave en la gestión de contenidos de la Web 2.0. El porqué de su necesario aparición en los planes de Estudio de Comunicación. Gonzálvez Vallés, J. E. (coord.), La Web 2.0 y 3.0 en su relación con el EES. Madrid: Visión Libros.

Arthur, W. (2007) The Authentic Enterprise [Online] New York: Arthur W. Page Society. http://www.awpagesociety.com/insights/authentic-enterprise-report/

Arthur, W. (2012) Building Belief: Corporate Character: How Leading Companies are Defining, Activating \& Aligning Values [Online] New York: Arthur W. Page Society. http://www.awpagesociety.com/insights/corporate-character/

Bardhan, N. (2003). Creating spaces for international and multi (inter)cultural perspectives in undergraduate public relations education. Communication Education, 52(2), 164-172. http://dx.doi.org/10.1080/03634520302473

Beurer-Zuellig, B., Fieseler, C., \& Meckel, M. (2009). A descriptive inquiry into the corporate communication profession in Europe. Public Relations Review, 35(3), 270-279. http://dx.doi.org/10.1016/j.pubrev.2009.03.002

Botan, C. H., \& Taylor, M. (2004). Public relations: state of the field. Journal of Communication, 54(4), 645-661. http://dx.doi.org/10.1111/j.1460-2466.2004.tb02649.x

Bronn, P. S. (2001). Communication managers as strategists? Can the make the grade?. Journal of Communication Management, 5 (4), 313-326. http://dx.doi.org/10.1108/13632540110806857

Brown, A., \& Fall, L. T. (2005). Using the port of entry report as a benchmark: survey results of on-the-job training among public relations internship site managers. Public Relations Review, 31(2), 301-304. http://dx.doi.org/10.1016/j.pubrev.2005.02.007

Brown, R. (2013). Digital PR is dead: Social goes mainstream' in B. Solis (Ed) (2013). Share This Too: More Social Media Solutions for PR Professionals. John Wiley \& Sons, London.

BVC, Dutch Professional Association for Communication (2002). Job profile descriptions in communication management, Third revised edition. The Hague, The Netherlands: BVC \& VVO.

Capriotti, P. (2009). Branding corporativo. Fundamentos para la gestión estratégica de la identidad corporativa. Santiago de Chile: Colección de Libros de la Empresa.

Castello, A. (2010). Una nueva figura profesional: el Community Manager. Revista de la Red Académica Iberoamericana de Comunicación, 1, 74-97.

Celaya, J. (2008). La empresa en la Web 2.0: El imparto de las redes sociales y las nuevas formas de comunicación 
online en la estrategia empresarial. Barcelona: Gestión 2000.

Celaya, J. (2008). La empresa en la Web 2.0: El imparto de las redes sociales y las nuevas formas de comunicación online en la estrategia empresarial. Barcelona: Gestión 2000.

Cheng, I. H., \& de Gregorio, F. (2008). Does (linking with) practice make perfect? A survey of public relations scholars' perspectives. Journal of Public Relations Research, 20(4), 377-402. http://dx.doi.org/10.1080/10627260802153298

Coleman, R., \& Wilkins, L. (2009). The moral development of public relations practitioners: a comparison with other professions and influences on higher quality ethical reasoning. Journal of Public Relations Research, 21(3), 318-340. http://dx.doi.org/10.1080/10627260802520462

Colorado, F. (2011). Complejidad y medios de comunicación en el espacio europeo. (Spanish). Revista CIDOB D'afers Internacionals, 95, 139-144.

Commission on Public Relations Education (2006). The Professional Bond: PR Education for the 21st Century, New York, Public Relations Society of America.

Commission on Public Relations Education (2011). Executive Summary of Three Studies [Online]. Institute for Public Relations. http://www.instituteforpr.org/topics/setting-standards-for-graduate-education-in-public-relations/

Corner, A., \& Cole, R. (2008). Are college graduates ill-prepared for PR writing? One PRSA Chapter weighs in. PR Tactics, June 2008, 9.

Corporate Communication Institute (2005), Communication Practices and Trends. [Online] Madison, NJ: Corporate Communication Institute. http://www.corporatecomm.org/pdf/MergedReport2005.pdf

Creedon, P., \& Al-Khaja, M. (2005). Public relations and globalization: building a case for cultural competency in public relations education. Public Relations Review, 31(3), 344-354. http://dx.doi.org/10.1016/j.pubrev.2005.05.021

Cutlip, S. M., Center, A. H., \& Broom, G. M. (2006). Effective Public Relations, 9th edition, Prentice Hall, Upper Saddle River, NJ.

De Bussy, N. M., \& Wolf, K. (2009). The state of Australian public relations: professionalisation and paradox. Public Relations Review, 35(4), 376-381. http://dx.doi.org/10.1016/j.pubrev.2009.07.005

(DPRG) Deutsche Public Relations Gesellschaft (ed.) (2005). Öffentlichkeitsarbeit, PR-Arbeit - Berufsfeld, Qualifikationsprofil, Zugangswege [public relations - field of occupation, qualification, access in the occupational field]. Bonn, Germany: DPRG. URL: http://www.pzok.de/_files/pruefung/Oeffentlichkeitsarbeit.pdf (16.1.2012).

DiStaso, M. W., Stacks, D. W., \& Botan, C. H. (2009). State of public relations education in the United States: 2006 report on a national survey of executives and academics. Public Relations Review, 35(3), 254-269. http://dx.doi.org/10.1016/j.pubrev.2009.03.006

Dolphin, R. R. (2002). A profile of PR directors in British companies. Corporate Communication: An International Journal, 7(1), 17-24. http://dx.doi.org/10.1108/13563280210416008

Dozier, D. M., \& Broom, G. M. (2006). The centrality of practitioner roles to public relations theory. in Botan, C.H and Hazleton, V., (eds) Public Relations Theory II, Lawrence Erlbaum, London, UK, 137-170.

Drake, J. L. (2006). Class masters: what PR pros must decide before pursuing a master's degree. PR Tactics, October 2006, 24-25.

Edwards, L. (2008). PR practitioners' cultural capital: an initial study and implications for research and practice. Public Relations Review, 34(4), 367-372. http://dx.doi.org/10.1016/j.pubrev.2008.06.004

Edwards, L. (2012). Public Relations’ Occupational Culture. K. Sriramesh and D. Verčič (Eds.). (2012). Culture and Public Relations: Links and Implications. Routledge.

European Higher Education Area (2013). Bologna Process - Higher Education Area [Online], European Higher Education Area. http://www.ehea.info/

Evans (2011). The Internet of Things How the Next Evolution of the Internet Is Changing Everything [Online] Cisco Internet Business Solutions Group. http://www.cisco.com/web/about/ac79/docs/innov/IoT_IBSG_0411FINAL.pdf

Fleischer, C. S. (2002). The development of competencies in international public affairs. Journal of Public Affairs, 3(1), 76-82. http://dx.doi.org/10.1002/pa.135

Freitag, A. R. (2002). Ascending cultural competence potential: an assessment and profile of US public relations practitioners' preparation for international assignments. Public Relations Research, 14(3), 207-227. 
http://dx.doi.org/10.1207/s1532754xjprr1403_3

Gregory, A. (2008). Competencies of senior communication practitioners in the UK: an initial study. Public Relations Review, 34 (3), 215-223. http://dx.doi.org/10.1016/j.pubrev.2008.04.005

Gregory, A. (2012). Practical Issues in Cross-Cultural Research Projects. Carayol, V. and Frame, A. (eds), Communication and PR From a Cross-cultural Standpoint: Practical and Methodological Issues, P.I.E Peter Lang, Oxford, 43-53. http://dx.doi.org/10.1108/ccij-04-2013-0022

Grunig, J. E., Grunig, L., \& Dozier, D. (2006). The Excellence Theory' in Rhetorical and Critical Perspectives of Public Relations. Botan, C.H and Hazleton, V., (eds) Public Relations Theory II, Lawrence Erlbaum, London, UK, 21-62. http://dx.doi.org/10.4324/9780203873397

Goodman, M. B. (2006). Corporate communication practice and pedagogy at the dawn of the new millennium. Corporate Communications: An International Journal, 11(3), 196-213. http://dx.doi.org/10.1108/13563280610680803

Hardin, M. C., \& Pompper, D. (2004). Writing in the public relations curriculum: practitioner perception versus pedagogy. Public Relations Review, 30(3), 357-364. http://dx.doi.org/10.1016/j.pubrev.2004.05.007

Hatzios, A. K. (2006). Perceptions of Utility and Importance of International Public Relations Education among Educators and Practitioners. A Thesis Submitted to the Graduate Faculty of the University of Georgia in Partial Fulfilment of the Requirements for the Degree, Master of Arts. Athens, Georgia: University of Georgia.

Heyman, W. C. (2005). Mix of personal, professional patterns signal likely success in PR profession. Public Relations Quarterly, 50(3), 45-47.

Holmström, S. (2010). Reflective management: Seeing the organization as if from outside”, in Heath, R.L., (Ed.), The SAGE handbook of public relations, Sage,

Thousand Oaks, C. A. 261-276. http://dx.doi.org/10.1108/09504121111145302

Ihlen, Ø., \& van Ruler, B. (2007). How public relations works: Theoretical roots and public relations perspectives. Public Relations Review, 33(3), 243-248. http://dx.doi.org/10.1016/j.pubrev.2007.05.001

Ihlen, Ø., van Ruler, B., \& Fredriksson, M. (Eds.). (2009). Public relations and social theory: Key figures and concepts. New York: Routledge.

Ihlen, Ø., \& Verhoeven, P. (2009). Conclusions on the domain, context, concepts, issues and empirical avenues of public relations. Ihlen, Ø., van Ruler, B., \& Fredriksson, M. (Eds.), Public relations and social theory: Key figures and concepts, Routledge, New York, 332-349.

Ihlen, Ø., \& Verhoeven, P. (2012). A public relations identity for the 2010s. Public Relations Inquiry, 1(2), 159-176. http://dx.doi.org/10.1177/2046147x11435083

Institute for the Future (2011) Future World Skills 2020 [Online], Palo Alto, Institute for the Future. http://www.iftf.org/our-work/global-landscape/work/future-work-skills-2020/

(ITU) International Telecommunication Union (2013). The World in 2013: ICT Facts and Figures [Online] Geneva: International Telecommunication Union. http://www.itu.int/en/ITU-D/Statistics/Pages/facts/default.aspx

Jeffrey, L. M., \& Brunton, M. A. (2011). Developing a framework for communication management competencies. Journal of Vocational Education and Training, 63(1), 57-75. http://dx.doi.org/10.1080/13636820.2010.549948

Juma, H. (2013).The Relevance of Intercultural Competency for International Public Relations Managers: an e-Delphi study. Leeds Metropolitan University, Hanze University of Applied Sciences, United Kingdom, Netherlands, May 2013.

Kim, E., \& Johnson, T. L. (2009). Sailing through the port: does PR education prepare students for the profession?' 12th Annual International Public Relations Research Conference. 'Research that Matters to the Practice', March $11-14$, 2009, Holiday Inn University of Miami Coral Gables, Florida.

Latchaw, J., Allen, C., \& Ogden, D. (2009). Public relations professionals as shapers of public information: the role of theory in their education. Studies in Media \& Information Literacy Education, 9(1), 18-27. http://dx.doi.org/10.3138/sim.9.1.003

Liu, B. F., Horsley, S., \& Levenshus, A. B. (2010).Government and corporate communication practices: do the differences matter? Journal of Applied Communication Research, 38(2), 189-213. http://dx.doi.org/10.1080/00909881003639528 
Linke, A., \& Zerfass, A. (2013). Social media governance: regulatory frameworks for successful online communications. Journal of Communication Management, 17(3), 270-286. http://dx.doi.org/10.1108/jcom-09-2011-0050

L'Etang, J. (1996). Public relations as diplomacy. L'Etang, J. and Pieczka, M. Critical Perspectives in Public Relations, International Thomas Business Press, London.

L'Etang, J. (2002). Public relations education in Britain: a review at the outset of the millennium and thoughts for a different research agenda. Journal of Communication Management, 7(1),43-53. http://dx.doi.org/10.1108/13632540310807241

Logeion (2012). Beroepsniveauprofielen [Job level profiles]. http://www.logeion.nl/beroepsniveauprofielen

McCleneghan, J. S. (2006). PR executives rank 11 communication skills. Public Relations Quarterly', 51(4), 42-46.

Moloney, K. (2000). Rethinking Public Relations: The Spin and the Substance. Routledge, London. http://dx.doi.org/10.4324/9780203030592

Moncur, C. (2006). Embracing PR theory: an opportunity for practitioners?. Journal of Communication Management, 10(1), 95-99. http://dx.doi.org/10.1108/13632540610646409

Monge, S. (2010). Community Manager. Cuando los blogs no son suficiente. Ponencia realizada en el marco del II Congreso de Ciberperiodismo y Web 2.0. http://www.sergiomonge.com/doc/community-manager.pdf

Moss, D., Newman, A., \& De Santo, B. (2005). What do communication managers do? Defining and redefining the core elements of management in public relations/corporate communication context. Journalism and Mass Communication Quarterly, 82 (4), 873-890. http://dx.doi.org/10.1177/107769900508200408

Okay, A., \& Okay, A. (2008). MA and doctoral public relations research in Turkey (1984-2007): A quantitative study of dissertations contribution to public relations field. Public Relations Review, 34(3), 312-314. http://dx.doi.org/10.1016/j.pubrev.2008.03.027

Oughton, L. (2004). Do we need core competences for local government communications?. Local Government Communication Leaders Development Programme, Ideas in Communication Leadership. London, UK: Improvement and Development Agency, pp.65-72.

Parnell, L. (2008). Experience vs. graduate school: what matters most. PR Tactics, November 2008, 16-18.

Pieczka, M. (2000). Objectives and evaluation in public relations work: what do they tell us about expertise and professionalism? Journal of Public Relations Research, 12(3), 211-233. http://dx.doi.org/10.1207/s1532754xjprr1203_1

Pieczka, M. (2002). Public relations expertise deconstructed. Media, Culture and Society, 24(3), 301-323. http://dx.doi.org/10.1177/016344370202400302

Proctor, R. W., \& Dutta, A. (1995). Skill Acquisition and Human Performance, Sage, London.

Reber, B. H., \& Berger, B. K. (2006). Finding influence: examining the role of influence in public relations practice. Journal of Communication Management, 10(3), pp. 235-249. http://dx.doi.org/10.1108/13632540610681130

Riedel, J. (2011). Was sind die Kompetenzen für Social Media? http://social-media-experten.de/2011/03/16/was-sind-die-kompetenzen-fur-social-media/

Rojas, P. (2011). Community Management en una semana, Gestión 2000, Barcelona.

Rose, P. (2002). The times they are a changing and so should PR training. Public Relations Quarterly, 47(1), 14-17.

Röttger, U., Preusse, J., \& Schmitt, J. (2009). Kommunikationsberufe im Wandel. Befunde einer qualitativen Studie zu veränderten Anforderungs- und Qualifizierungsprofilen. Dernbach, B. and Quandt, T. (Hrsg.) Spezialisierung im Journalismus, Wiesbaden: VS-Verlag für Sozialwissenschaften. S., 221-226. http://dx.doi.org/10.1007/978-3-531-91582-1_18

Schuhmann, U. (2007). Interner Manager oder Betriebsjournalist? Welche Anforderungen werden an das Arbeitsfeld der internen Kommunikation gestellt? [internal manager or journalist within the corporation?] Dörfel, L. (Hrsg.): Interne Kommunikation - Die Kraft entsteht im Maschinenraum. Berlin: scm \% prismus GmbH. URL: http://www.schuhmann-pb.de/fileadmin/Downloads/News/PRThemen/01_InternerManager.pdf

Schick, E., \& Mickeleit, T. (2010). Ein PlaÅNdoyer für das PR-- - Volontariat. Bundesverband deutscher Pressesprecher (BdP) \& Deutsche Public Relations Gesellschaft (DPRG) (Hrsg.): Das PR--VolontariatPR--Qualifizierung

In deutschen Agenturen und Unternehmen. Berlin, Germany: Helios Media. 
Schulte, S. (2011). Qualfikation für Public Relations - Neue Perspektiven in der PR-Berufsfeldforschung. Münster: Univ. Münster, Dissertation.

Sha, B. L. (2011). 2010 practice analysis: professional competencies and work categories in public relations today. Public Relations Review, 37(3), 187-196. http://dx.doi.org/10.1016/j.pubrev.2011.04.005

Sha, B. L. (2011a). Does accreditation really matter in public relations practice? How age and experience compare to accreditation. Public Relations Review, 37(1), 1-11. http://dx.doi.org/10.1016/j.pubrev.2010.11.004

Soderbery, R. (2013). How Many Things Are Currently Connected To The "Internet of Things" (IoT)?. Forbes [Online], http://www.forbes.com/sites/quora/2013/01/07/how-many-things-are-currently-connected-to-the-internet-of-things -iot/

Steiner, C. J. (2001). How important is professionalism to corporate communication?. Corporate Communications: An International Journal, 6(3), 150-156. http://dx.doi.org/10.1108/eum0000000005739

Sriramesh, K. (2009). Globalisation and public relations: An overview looking into the future. Prism, 6(2), 1-11.

Szyszka, P. (1995). Öffentlichkeitsarbeit und Kompetenz: Probleme und Perspektiven künftiger Bildungsarbeit. In: Bentele, G. \& Szyszka, P. (Hrsg.): PR-Ausbildung in Deutschland. Entwicklung, Bestandsaufnahme, Perspektiven. Opladen: Westdeutscher Verlag. http://dx.doi.org/10.1007/978-3-322-94205-0_33

Sun, W., Stewart, J., \& Pollard, D. (Eds.). (2011). Corporate governance and the global financial crisis: International perspectives. Cambridge University Press,Chicago http://dx.doi.org/10.1017/cbo9780511736599

Tench, R., Zerfass, A., Verhoeven, P., Moreno, A., \& Verčič, D. (2012). ECOPSI Benchmarking Preliminary Report. Leeds, UK: Leeds Metropolitan University.

Tench, R., \& Moreno, A. (2015). Mapping communication management competencies for European practitioners: ECOPSI an EU study. Journal of Communication Management, 19 (1), 39-61. http://dx.doi.org/10.1108/jcom-11-2013-0078

Toth, E. L. (Ed.). (2006). The future of excellence in public relations and communication management: Challenges for the next generation. Routledge. http://dx.doi.org/10.4324/9781410613967

Toth, E. L., \& Aldoory, L. (2010). A First Look: Analysis of Global Public Relations Education [Online]. Commission on Public Relations Education. http://www.commpred.org/firstlook/

Tranfield, D., Denyer, D., \& Smart, P. (2003). Towards a Methodology for Developing Evidence-Informed Management Knowledge by Means of Systematic Review. British Journal of Management, 14(3), 207-222. http://dx.doi.org/10.1111/1467-8551.00375

Van Leuven, J. K. (2012). Public relations: The profession and the practice. McGraw-Hill.

van Ruler, B. (2000). Communication Management in The Netherlands. Public Relations Review, 26(4), 403-423. http://dx.doi.org/10.1016/s0363-8111(00)00056-4

van Ruler, B., Verčič, D., Bütschi, G., \& Flodin, B. (2000). The European Body of Knowledge on Public Relations / Communication Management: The Report of the Delphi Research Project 2000. Ghent/Ljubljana: European Association for Public Relations Education and Research.

van Ruler, B. (2005). Commentary: professionals are from Venus, scholars are from Mars. Public Relations Review, 31(2)2, 159-173. http://dx.doi.org/10.1016/j.pubrev.2005.02.022

van Ruler, B., \& Verčič, D. (2005). Reflective communication management: Future ways for public relations research", in Kalbefleisch, P. J. (Ed.), Communication Yearbook, 29, 239-274. Lawrence

Erlbaum, M. N. J. http://dx.doi.org/10.1207/s15567419cy2901_8

van Ruler, B., \& Elving, W. (2007). Carrière in Communicatie [Career in communication]. Amsterdam: Boom.

Werhane, P. (2012). Globalization and its Challenges for Business and Business Ethics in the Twenty - First Century. Business and Society Review, 117(3), 383-405. http://dx.doi.org/10.1111/j.1467-8594.2012.00410.x

Winterton, J., Delamare-Le Deist, F., \& Stringfellow, E. (2005). Typology of Knowledge, Skills and Competences: Clarification of the Concept and Prototype. Thessaloniki: CEDEFOP.

Zerfass, A., Moreno, A., Tench, R., Verčič, D., \& Verhoeven, P. (2008). European Communication Monitor 2008. Trends in Communication Management and Public Relations-Results and Implications. Brussels/Leipzig, Germany: EUPRERA, University of Leipzig.

Zerfass, A., Moreno, A., Tench, R., Verčič, D., \& Verhoeven, P. (2009). European Communication Monitor 2009. 
Trends in Communication Management and Public Relations-Results of a Survey in 34 Countries. Brussels: EACD, EUPRERA.

Zerfass, A., Tench, R., Verhoeven, P., Verčič, D., \& Moreno, A. (2010). European Communication Monitor 2010. Status Quo and Challenges for Public Relations in Europe. Results of an Empirical Survey in 46 Countries. Brussels: EACD, EUPRERA.

Zerfass, A., Van Ruler, B., Rogojinaru, A., Verčič, D., \& Hamrefors, S. (2007). European Communication Monitor 2007. Trends in Communication Management and Public Relations-Results and Implications. Brussels/Leipzig, Germany: EUPRERA, University of Leipzig.

Zerfass, A., Verhoeven, P., Tench, R., Moreno, A., \& Verčič, D. (2011). European Communication Monitor 2011. Empirical Insights into Strategic Communication in Europe. Results of an Empirical Survey in 43 Countries. Brussels: EACD, EUPRERA.

Zerfass, A., Verhoeven, P., Tench, R., Moreno, A., \& Verčič, D. (2012). European Communication Monitor 2012. Challenges and Competencies for Strategic Communication: Results of an Empirical Survey in 42 Countries. Brussels: EACD, EUPRERA.

Zerfass, A., Moreno, A., Tench, R., Verčič, D., \& Verhoeven, P. (2013). European Communication Monitor 2013. A Changing Landscape - Managing Crises, Digital Communication and CEO Positioning in Europe. Results of a Survey in 43 Countries. Brussels: EACD, EUPRERA.

Zerfass, A., Tench, R., Verčič, D., Verhoeven, P., \& Moreno, A. (2014). European Communication Monitor 2014. Excellence in Strategic Communication - Key Issues, Leadership, Gender and Mobile Media. Results of a Survey in 42 Countries. Brussels: EACD, EUPRERA, Helios Media.

This work is licensed under a Creative Commons Attribution 3.0 License. 